\title{
Political Economy of Cross-Strait Relations
}

\author{
Ekaterina O. Nakhatakyan \\ MGIMO University, Moscow, Russian Federation
}

\begin{abstract}
The article provides a comprehensive analysis of the interrelation of political and economic factors in Cross-Strait relations. The main political factor considered in the study is the policy of the ruling party in Taiwan towards the Mainland, its acceptance of Beijing's "One China" policy and "1992 Consensus", put forward by Mainland China as a political basis for building Cross-Strait dialogue between the parties. Key economic factors include economic cooperation and exchanges between the two sides in such fields as bilateral trade, international capital flows and tourism. The relevance of the study refers to the settlement of the so-called Taiwan issue and the implementation of the complete reunification of the People's Republic of China that embodies one of the fundamental interests of Mainland China. The aim of the research is to examine the impact of political cycle in Taiwan on the economic cooperation between Beijing and Taipei, the further intensification of which could lead to the peaceful reunification through economic integration. The study provides a broad overview of the development of relations between Taiwan and Mainland China, focusing on the policies of the Taipei administrations from 1949 to 2019 and its impact on economic cooperation between the two sides. The methodological framework of the paper is mainly based on international political economy. The results of the research suggest that political cycle in Taiwan has almost no impact on Cross-Strait trade and investment. Meanwhile it has quite significant influence on Cross-Strait tourism, especially from the PRC, as it has the administrative means of regulation of the number of Mainland tourists wishing to visit Taiwan.

Key words: Cross-Strait relations, Mainland China, PRC, ROC, Taiwan, Kuomintang party, Democratic progressive party, 1992 Consensus, One China policy, Taiwan Strait

For citation: Nakhatakyan, E.O. (2021). Political Economy of Cross-Strait Relations. Vestnik RUDN. International Relations, 21(1), 136-147. DOI: 10.22363/2313-0660-2021-21-1-136-147
\end{abstract}

\section{Политическая экономия отношений КНР и Тайваня}

\author{
E.O. Нахатакян \\ МГИМО МИД России, Москва, Российская Федерация
}

\begin{abstract}
Аннотация. Представлен всесторонний анализ взаимосвязи политических и экономических факторов в отношениях между материковым Китаем и Тайванем. Основным политическим фактором, учитываемым в исследовании, является позиция правящей партии на Тайване в отношении материка, принимающей политику Пекина «Один Китай» и «Консенсус 1992 года», выдвинутого материковым Китаем в качестве политической основы для выстраивания диалога между сторонами. Ключевые экономические факторы охватывают такие сферы сотрудничества между Пекином и Тайбэем, как двусторонняя торговля, международное движение капитала и туризм. Актуальность исследования определяется тем фактом, что урегулирование тайваньского вопроса и реализация полного воссоединения Китайской Народной Республики являются фундаментальными интересами материкового Китая. Цель статьи - анализ влияния политического цикла на Тайване на экономическое сотрудничество между Пекином и Тайбэем, дальнейшая интенсификация
\end{abstract}

(C) Nakhatakyan E.O., 2021

This work is licensed under a Creative Commons Attribution 4.0 International License.

https://creativecommons.org/licenses/by/4.0/ 
которого может привести к мирному воссоединению путем экономической интеграции. Представлен широкий обзор развития отношений между Тайванем и материковым Китаем с акцентом на политике администраций Тайбэя с 1949 по 2019 г. и ее влияния на экономическое сотрудничество между двумя сторонами. В основе методологии исследования лежит международная политическая экономия. Основные результаты позволяют сделать вывод, что политический цикл на Тайване практически не влияет на торговлю и инвестиционную деятельность между материковым Китаем и Тайванем, однако оказывает значительное влияние на туризм, в особенности со стороны КНР, которая может административным путем регулировать (сокращать или увеличивать) количество материковых туристов, желающих посетить Тайвань.

Ключевые слова: отношения между материковым Китаем и Тайванем, материковый Китай, КНР, Китайская Республика, Тайвань, Гоминьдан, Демократическая прогрессивная партия, Консенсус 1992 года, политика «Одного Китая», Тайваньский пролив

Для цитирования: Nakhatakyan E.O. Political Economy of Cross-Strait Relations // Вестник Российского университета дружбы народов. Серия: Международные отношения. 2021. T. 21. № 1. С. 136-147. DOI: 10.22363/2313-0660-2021-21-1-136-147

The so-called Taiwan issue constitutes one of the longest-running unsolved international political and security problems inherited from the Cold War. Taiwan question became prominent in international relations after the civil war in China in 1945-1949 that resulted in the retreat of the Kuomintang party (KMT) to Taiwan, where it continued to position itself as the legitimate government the Republic of China (ROC), established in 1911 [Edmonds, Goldstein 2001: 213]. At the same time, the People's Republic of China (PRC) was established on the Mainland by the winner Chinese Communist Party that was claiming itself to be the sole representative of the Chinese nation. As long as the United States with most of the international community and Western bloc continued recognizing the ROC government as the legitimate government of China and supported it as such in international organizations notably in the United Nations where the KMT proceeded to represent China, the regime's claim was given a degree of credibility.

In the 1970s after the realignment of power in East Asia and the rapprochement between the PRC and the U.S. the situation changed dramatically. As a result, in 1971 Taiwan was forced to withdraw from the UN. Following it as well as the U.S. de-recognition of the ROC and official recognition of the PRC in 1979 the capitalist states one-by-one shifted their recognition and began to recognize the $\mathrm{PRC}$ as the representative of the whole China. However, the existence of autonomous Taiwan administration and a number of diplomatic allies threatens the Mainland China's legitimacy to be the sole ruler and representative of the Chinese nation and runs counter to the "One China" policy, which means that there is only one China (PRC) in the world and Taiwan is an inalienable part of China.

Although the first measures taken by the government of the Mainland China to reintegrate Taiwan were the military ones that resulted in military conflicts in 1954, 1955 and 1958. Gradually they were transformed into economic measures. The latter were the result of the institutionalization of Cross-Strait relations and expansion of Cross-Strait economic cooperation that took place in the 1990s. Under the impact of the PRC's economic reforms as well as Taiwan's democratization since the late 1980s Beijing and Taipei established informal channels of communication, such as the Straits Exchange Foundation (SEF) and the Association for Relations Across the Taiwan Straits (ARATS) [Wei-Cheng Wang 2002: 121]. The two sides also increased their economic cooperation and overall improved relations.

However, despite entering the new era of peaceful development of Cross-Strait relations the main political factor that continues to influence Cross-Strait economic cooperation and exchanges has been the political attitude of the ruling party in Taiwan towards Cross-Strait relations and its acceptance of Beijing's so-called precondition ("One China" principle), which is considered to be a political foundation for CrossStrait dialogue.

The relevance of the analysis refers to the settlement of the Taiwan issue and realization of 
the complete reunification of China that embodies one of the fundamental interests of Mainland China. The novelty of the research is a broad analysis of different approaches of Taiwan's administration towards "One China" policy, Beijing's reaction to their policies and the whole impact of political factors on economic cooperation between the two sides in such fields as trade, international capital flows and tourism.

The research methodology is interdisciplinary and combines quantitative and qualitative, genetic, historical, economic and political methods. Genetic and historical methods are used to analyze the stages of development of Cross-Strait relations at different periods and under several administrations. Economic methods include structural and dynamic comparison, factor analysis and correlation analysis. Structural and dynamic comparison is used to compare economic indicators over different time periods. Political methods mainly include casestudy method that analyzes limited number of events, objects or conditions and their relationships. As political and economic factors are analyzed together the concept of international political economy (IPE) is also used.

The bibliography includes the publications of D. Fell [2012], J.B. Jacobs [Jacobs, I-hao 2007], E. Dagdag [2005], Chien-min Chao [2003], Wei-Cheng Wang [2002], F. Muyard [2010], J.-P. Cabestan [Cabestan, deLisle 2014], G. Lin [2019], Y. Matsuda [2015], K. Churchman [2016] and others, which examine Cross-Strait relations during Lee Teng-hui, Chen Shui-bian, Ma Ying-jeou or Tsai Ing-wen administrations. The research provides the broad review of the development of Cross-Strait relations under Taiwanese administrations from 1949 to 2019 with specific focus on their policies and their impact on economic cooperation and exchanges between the two sides. Thus, the core of the research is the analysis of Cross-Strait dynamics under the perspective of interrelation of political and economic factors.

\section{Cross-Strait Trade}

There are two main political parties in Taiwan that support Taiwan's status-quo but at the same share opposing approaches towards
Mainland China: the Kuomintang party (KMT) and the Democratic progressive party (DPP). The KMT has pro-unification platform that promotes dialogue with the Mainland China under the "1992 Consensus", adheres to the title of ROC for Taiwan, accepts the "One China" principle and prioritizes Cross-Strait relations over foreign relations, claiming that only through better relations with the Mainland Taiwan can overcome an international isolation and improve international presence. The DPP, on the contrary, has pro-independence platform that doubts the existence of the "1992 Consensus", does not accept the "One China" principle, priorities foreign relations over the Cross-Strait relations and emphasizes Taiwanese identity. Intuitively we can assume that the Cross-Strait economic cooperation and exchanges should thrive during the KMT leadership and stagnate during the DPP one.

As Taiwan went through three waves of power transition ${ }^{1}$ the Cross-Strait economic cooperation and exchanges should have a zigzag course: increasing during the KMT leadership and decreasing during the DPP leadership (see Fig. 1).

However, according to Mainland Affairs Council statistics, the change of the ruling party in Taiwan does not profoundly influence CrossStrait economic cooperation. For instance, as a general trend Cross-Strait trade has been increasing since 1991 (President of the Republic of China Lee Teng-hui's period) despite the power transition (see Fig. 2).

The analysis of the Cross-Strait economic cooperation has been based on the data since Lee Teng-hui's period as during Chiang Kai-shek dictatorship (1949-1975) Taiwan was to a large degree cut off from the Mainland China. There was no direct or indirect trade and citizens of either side of the Taiwan Strait could not pass the border [Fell 2012: 153]. During his son Chiang Ching-kuo's leadership (1978-1988) CrossStrait relations began to improve gradually. Although initially Chiang Ching-kuo continued

${ }^{1}$ After 50 years of the KMT's leadership in 2000 the DPP became the ruling party for the first time, in 2008 the KMT came to power again but in 2016 it lost its power and the DPP became the ruling party. 


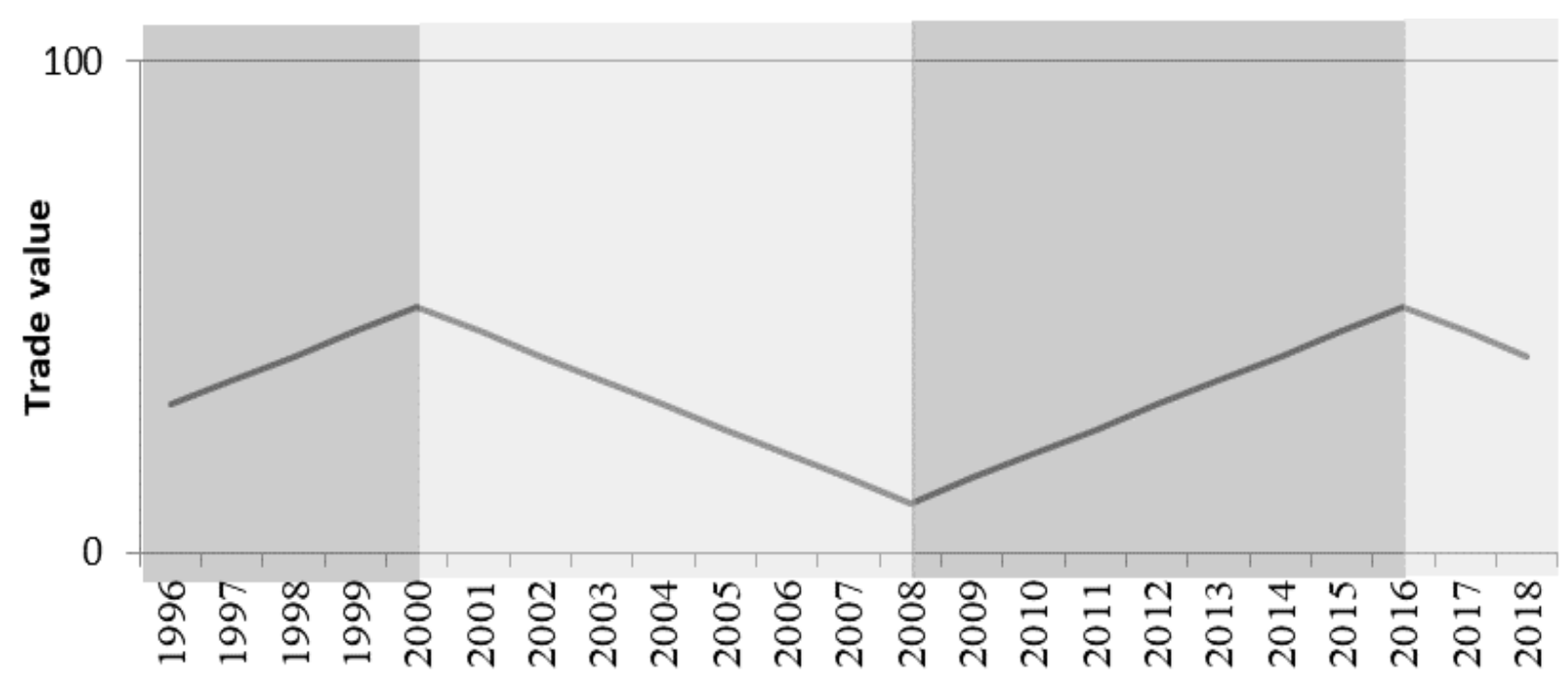

Fig. 1. Projection of Political Cycle on Trade Relations across the Straits, 1996-2018

Note: dark grey zone shows the KMT leadership; light grey zone shows the DPP leadership.

0 is the lowest value of trade; 100 is the highest value of trade

Source: compiled by the author.

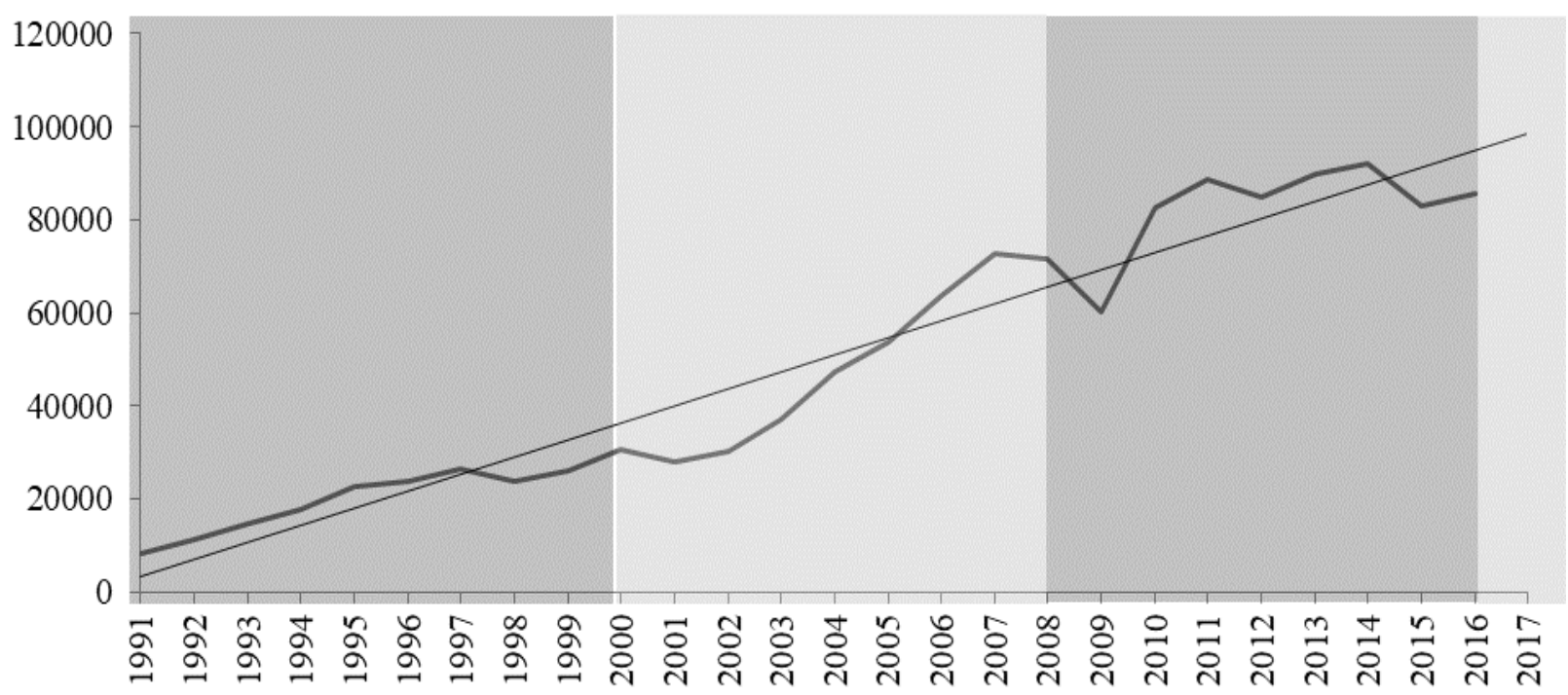

Fig. 2. Cross-Strait Trade, millions USD, 1991-2016

Note: dark grey zone shows the KMT leadership; light grey zone shows the DPP leadership.

Source: compiled by the author according to the estimation method of Mainland Affairs Council. 2020.

URL: http://www.mac.gov.tw (accessed: 21.02.2019).

to pursue his father's Cross-Strait policy and rejected Mainland China's initiative to establish Three Links (trade, transportation and mail) by announcing the "Three Noes" policy of no negotiations, no contacts and no compromise with the CPC (Communist Party of China).

At the end of his leadership Chiang Chingkuo shifted from the "Three Noes" policy to pragmatic diplomacy that resulted in dramatic developing of indirect Cross-Strait trade, mainly via Hong Kong, and became a solid base for further Cross-Strait relations [Fell 2012: 154]. However, despite Chiang's moderate policy in the late 1980s that included the lift of martial law and many long-term political bans Cross-Strait relations were still in their infancy. The passing of Chiang Ching-kuo in 1988 led to the breakdown of authoritarian regime and transition to democracy in Taiwan. 
Under Lee Teng-hui's leadership (19882000) a new stage of Cross-Strait relations started. The two sides moved towards the institutionalization of Cross-Strait relations. National Unification Council was founded in 1990. During its third meeting on February 23, 1991 the National Unification Guidelines (NUG) that outlined major steps towards unification were adopted. Another important bodies created at the time were the Mainland Affairs Council (MAC) in Taiwan and the Taiwan Affairs Office (TAO) in Mainland China [Jacobs, I-hao 2007: 381]. Moreover, in order to launch talks between the two sides on semi-official basis nongovernmental bodies were also established: the Straits Exchange Foundation (SEF) in Taiwan and Association for Relations across the Taiwan Straits (ARATS) in Mainland China [Jacobs, I-hao 2007: 381].

In 1991 the two sides launched formal SEF-ARATS talks to discuss relationship and the competing "One China" principle. In 1992 during the meeting in Hong Kong they adopted the so called "1992 Consensus", according to which two sides of the Taiwan Straits agreed that there is only one "China": both Mainland China and Taiwan belong to the same China. Although Beijing and Taipei defined the meaning of the "China" differently (Beijing insists that "China" means the People's Republic of China with Taiwan as a "Special Administrative Region", Taipei in contrast considers "China" as the Republic of China with de jure sovereignty over all of China) it was the first political compromise reached between Taiwan and Mainland in over 40 years [Fell 2012: 158]. Thus, it is naturally to analyze Cross-Strait economic cooperation and exchanges from 1991 when Cross-Strait dialogue between the two sides was established.

From 1991 to 1995 Cross-Strait indirect trade (via Hong Kong) significantly increased with average annual growth rate of $29 \%$. However, in 1995 the growth rate accounted for only $5 \%$ due to several reasons:

1) the announcement of "Go South" policy by Lee Teng-hui that was targeted to develop relations with Southeast Asia;

2) the deterioration of Cross-Strait relations after Lee's visit to the U.S. that was strongly condemned in the Mainland China. Even the negotiations between the two sides were postponed in 1995. Furthermore, during the same year Mainland China conducted military exercises close to the island that provoked antiChinese sentiments in Taiwan [Fell 2012: 162].

In 1998 the annual growth rate of trade dropped to a negative $9.1 \%$ as a result of Asian financial crisis together with Lee's proindependence speeches and his policy shift towards expanding international cooperation rather than developing Cross-Strait relations. In 1999 volume of trade almost reached the level of 1997, however the Cross-Strait tensions continued to increase. In 1999 SEF-ARATS talks were ceased by Beijing after Lee's interview for Deutsche Welle, where he stated that the relations between Taiwan and the Mainland China were state-to-state or special state-to-state relations [Jacobs, I-hao 2007: 389].

In 2000 Chen Shui-bian, the DPP's candidate, won presidential elections in Taiwan. Despite Beijing's distrust towards the DPP and Chen personally and its insistence to accept "One China" principle and "1992 Consensus" as a precondition for Cross-Strait dialogue CrossStrait economic cooperation and exchanges expanded dramatically [Wei-Cheng Wang 2002: 92]. Although Chen did not accept the "One China" principle he tried to reduce Cross-Strait tensions by switching to more pragmatic diplomacy and gaining mutual benefits through economic cooperation with the Mainland China [Dagdag 2005: 76].

From 2001 to 2007 Cross-Strait indirect trade (via Hong Kong) increased dramatically the average annual growth rate accounted for $17.3 \%$. The boost of trade in 2001 was a result of an establishment of Three Mini-Links (direct transportation, trade and postal services between the offshore islands Kinmen, Matsu and Penghu and Chinese Province of Fujian). However, further trade growth between the two sides cannot be explained by Chen's Cross-Strait policy [Chien-min 2003: 131].

In 2002 he switched from "political integration" formula that was proposed in 2001 to "state-to-state" concept that provoked CrossStrait tensions [Wei-Cheng Wang 2002: 119]. 
During the second term of his presidency Chen proceeded with a more assertive policy. In 2007 he addressed a speech at the 25th anniversary of the Formosan Association for Public Affairs publicly announcing his desire for Taiwan's independence and new constitution that caused the escalation of Cross-Strait tensions. Nevertheless, the Cross-Strait trade was growing during the whole Chen's period with a slight decline at the beginning of 2008, the year of presidential elections in Taiwan [Lychagin, Komarov 2017: 535]. Total trade volume increased in more than two times since 2000. In 2008 it accounted for 71.7 billion USD, in contrast to 2000 when it accounted for 30.6 billion USD (Fig. 2).

After 2008 elections in Taiwan when the KMT came back to power a new stage in CrossStrait relations started. New China policy of President of the Republic of China Ma Yingjeou's (2008-2016) was focused on lowering the Cross-Strait tensions and strengthening economic ties with the Mainland China [Cabestan, deLisle 2014: 125]. After Ma's acceptance of the "1992 Consensus" in his 2008 inaugural address the Cross-Strait dialogue was resumed through the semi-governmental organizations: the SEF for Taiwan and the ARATS for Mainland China. Since first round of SEF-ARATS talks in 2008 they had been conducted every six months and by the end of Ma's leadership resulted in signing of 23 CrossStrait agreements, which were directly related to economic exchanges [Lin 2019: 181]. However, Cross-Strait trade sharply decreased in 2008 because of the global financial crisis that hit Taiwan with full force in the fourth quarter of 2008. In 2009 Cross-Strait trade dramatically recovered.

One of the main achievements of Ma's administration was the signing in 2010 of the Economic Cooperation Framework Agreement (ECFA) which was adopted to expand access to the Chinese market by strengthening investment guarantees, and providing tariff reductions and protection of intellectual property rights [Fuller 2014: 97]. In 2011 the annual growth rate of trade accounted for $7.5 \%$ and in 2012, the year of Taiwan's presidential election, it dropped to a negative growth of $4 \%$ and recovered back to $5.4 \%$ in 2013. In 2014 the annual growth rate of trade increased slightly and accounted for $2.9 \%$ as a result of follow-up agreements to the ECFA, for instance, Cross-Strait Customs Cooperation Agreement (2012).

However, in 2015 bilateral trade decreased sharply to a negative growth rate of $9.8 \%$. The main reasons for such drop were growing concerns of Taiwan's economic dependence on Mainland China and public discontent with Ma's Cross-Strait policy [Matsuda 2015: 6], especially after signing the Cross-Strait Agreement on Trade in Services in 2013 that according to many Taiwanese could lead to increasing asymmetric competition as Taiwan's service sector consisted of small- and medium-sized enterprises (SME), in contrast to Mainland China where the majority of the market was divided between large stateowned enterprises (SOE) [Fell 2012: 161].

Thus, the Taiwanese companies that could not compete with the Chinese ones are likely to lose competition or even be forced to leave the market. This in turn would negatively affect the welfare of the Taiwanese population that could lose their work places or face the reduction in salary. As a result, in 2014 Taiwanese students and social activists organized the "Sunflower movement" that paralyzed the ratification of the Cross-Strait Agreement on Trade in Services and limited Ma's further Cross-Strait policy. Although new agreements (Cross-Strait Agreement on Avoidance of Double Taxation and Enhancement of Tax Cooperation and CrossStrait Collaboration Agreement on Flight Safety and Airworthiness) were signed in 2015 [Tsai, Tony 2017: 32]. They mainly improved the institutional foundation for contacts across the Strait but did not have a significant effect on the Cross-Strait trade.

Although the election campaign took place on 16 January 2016 and the DPP's candidate Tsai Ing-wen won the presidential elections [Yitan, Enyu 2016: 7], the annual growth rate of Cross-Strait trade accounted for $3.1 \%$ in 2016 that was a sign of economic recovery after 2015 decline.

Thus, according to the Cross-Strait dynamics the political transition in Taiwan had 
little or almost no influence on Cross-Strait trade [Min-hua 2015]. Moreover, during Chen Shuibian administration that had a sharp proindependence stance and provoked tensions in Cross-Strait relations the trade volume continued to increase to even a greater degree than during Lee and Ma administrations due to economic rather than political factors.

\section{Cross-Strait Investment}

Taiwanese investment in Mainland China (TIC) tends to fluctuate from year to year (Fig. 3). In fact, there was no impact of the turnovers of political power in Taiwan in 2000, 2008 and 2016 on the amount of TIC. On the contrary to the KMT's and the DPP's attitude towards Cross-Strait relations, TIC increased in 2001, one year after the DPP took power, decreased in 2009, one year after the KMT took power and increased in 2016, the year when the DPP again took power. Thus, trend of TIC has not been closely linked to the political administrations' orientation and it is more related to Taiwanese business considerations and economic motivations. Moreover, TIC has been greatly influenced by the macroeconomic environment in Mainland China.
In 1979 Mainland government released a "Message to Compatriots in Taiwan" (高台湾同胞书) proposing open up of economic exchanges [Tsai C. 2017: 137]. Several preferential policies were also announced to promote TIC by Mainland China such as "Regulations on Encouraging the Investments of Taiwan Compatriots" (关于鼓励台湾同胞投资的规定) in 1988 that provided very comprehensive and detailed regulations on how Taiwanese entrepreneurs could invest in Mainland China and the "Law Regarding the Protection of Investment by Taiwan Compatriots” (台湾同胞投资保护法) in 1994 that was aimed to protect and encourage TIC [Tsai C. 2017: 137].

Moreover, in 1984 Mainland China's State Council passed the "Special Preferential Regulations on Taiwanese Patriots' Investment in the Special Economic Zones" (关于台湾同胞到经济特区投资的特别优惠办

法) to make it easier for Taiwanese investors to invest in the special economic zones (Shenzhen, Zhuhai, Shantou, Xiamen) that were established in 1979 [Tsai C. 2017: 138]. The first wholly

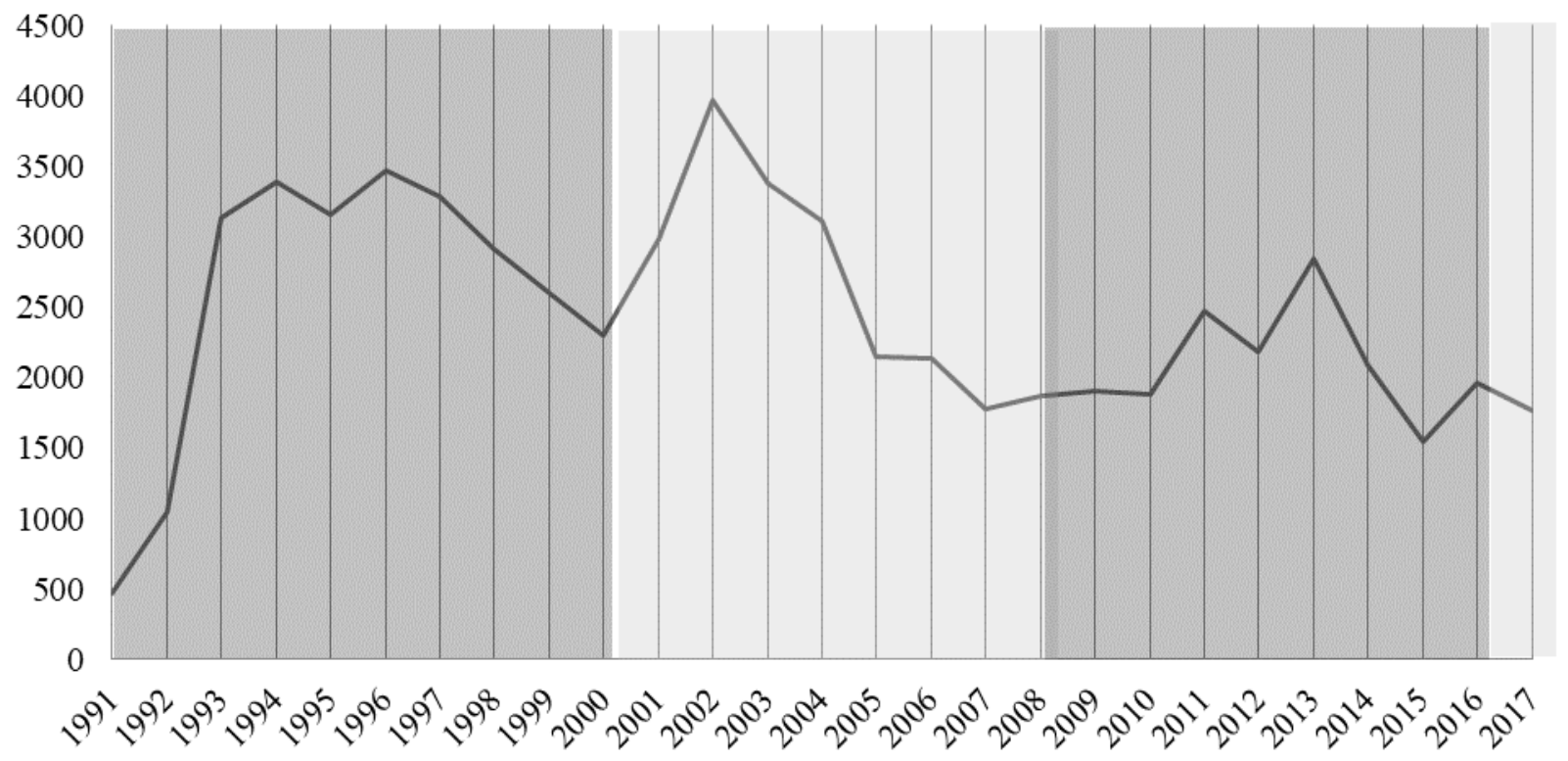

Fig. 3. Taiwan's Investment in Mainland China (TIC), million USD

Note: dark grey zone shows the KMT leadership; light grey zone shows the DPP leadership.

Source: Cross-Strait Economic Statistics // Mainland Affairs Council. 2020.

URL: http://www.mac.gov.tw (accessed: 15.05.2019). 
owned Taiwanese enterprise was established in Fuzhou in 1984. However, in the 1980s TIC was still limited because of Taiwanese government's restriction.

Taiwanese government lifted the ban on foreign exchanges and facilitated capital outflow in 1987. This policy shift substantially promoted TIC. In 1990, Lee administration announced the "Measures on Indirect Investment and Technical Cooperation with the Mainland" and officially lifted the ban on investing in Mainland China. Since then many Taiwanese entrepreneurs have moved their factories to Mainland China to reduce labor costs. In 1992, TIC accounted for 1050 million USD that more than doubled in comparison with 1991 (466 million USD). Due to the economic reforms and open-up policy aiming to establish the socialist market economy system the growth of TIC continued at even a greater pace in 1993 (3139 million USD) (see Fig. 3). By 1995 more than a half of Taiwan's overseas investment has gone to the Mainland China [Fell 2012: 153].

However, the announcement of "Go South" policy by Lee administration together with the anti-Chinese sentiments in Taiwan after of the PRC conducted military exercises close to the island in 1995 led to a slight decrease of TIC. Lee administration was also concerned about Taiwan's economic dependence on the Mainland. Thus, in 1996 Lee limited the investment flows to the Mainland China announcing the "Go Slow, Be Patient" policy that strictly regulated Taiwanese investments in Chinese infrastructure and IT projects, and determined that Taiwanese individual investments should not exceed 50 million USD [Fell 2012: 153]. Despite Lee's tough attitude towards Mainland China and the implementation of new regulations on TIC there was only a slight decline of TIC in 1997. The sharp drop of TIC was in 1998 and 1999 after the Asian financial crisis in 1997.

During Chen Shui-bian's period the DPP promoted TIC and provided tax breaks lowinterest loan funds and subsidies to stimulate Taiwanese companies to invest in Mainland China [Shaocheng 2009: 251]. In 2001 during the Economic Development Advisory
Conference Chen replaced the "Go Slow, Be Patient" policy with the new policy of "Active Opening, Effective Management" that eliminated the 50 million USD cap on individual investments in Mainland China and simplified review process for Mainland-bound investments of less than 20 million USD [Wei-Cheng Wang 2002: 150].

Taiwanese banks were also allowed to transfer money directly to and from Chinese banks through special offices and offshore accounts. These initiatives led to the increase of TIC. However, the main reason for such a boost of TIC was the joining of Mainland China to the WTO in 2001, which improved its institutional investment environment and strengthened Taiwanese investors' confidence in investing in the PRC. That led to the growth for TIC in 2002 when it reached its peak and accounted for 3971 million USD (see Fig. 3). In 2002, Taiwan became a very important investor in the Mainland China; it was the second largest source of FDI into the Mainland China. Taiwan also had the third highest amount of contracted FDI and the fourth highest amount of investment projects realized in Mainland.

However, during Chen Shui-bian's second term TIC decreased significantly because of the deterioration of Cross-Strait relations. By the end of Chen's period the amount of TIC accounted for only 1774 million USD (see Fig. 3), even less than after the Asian financial crisis. The main reason was the distrust of Taiwanese investors towards Chen's Cross-Strait policy and their concerns of possible Mainland China's response to Chen's pro-independence speeches.

Ironically, even during the tenure of the KMT President Ma Ying-jeou the amount of TIC continued to decrease, especially after the global financial crisis. In 2011, TIC abruptly rose after signing the ECFA in 2010 [Lin 2012: 5]. In 2013, TIC slightly increased, after signing the Cross-Strait Investment Protection and Promotion Agreement in 2012. However, the amount of TIC was still less than during first years of Lee and Chen administrations. Despite the KMT's promotion of economic cooperation with the Mainland China during the whole Ma's period TIC fluctuated on the low level. This fact 
can be explained by rising labor costs and increased competition in Mainland China. More and more multinational corporations started investing in Mainland [Yi-Wen, Ko-Chia, TseChun 2016: 11]. Moreover, Mainland's own domestic enterprises gradually developed and became competitive after experiencing economic reforms for two consecutive decades. Thus, the fluctuation of actual TIC can be contributed to the shifting economic environment in the Mainland China 2000s.

During Tsai Ing-wen's presidency the amount of TIC dropped slightly and accounted for 1770 million USD in 2017 (see Fig. 3). The decline of TIC is likely to continue because of the stagnation of Cross-Strait relations as Tsai does not accept the "One China" principle and the "1992 Consensus" that rise the concerns of Taiwanese investors in possible Beijing's "punishment" measures in forms of economic sanctions. Moreover, rising labor costs in Mainland China and Tsai's New Southbound Policy led to the relocation of Taiwanese entrepreneurs' factories from Mainland China to developing Southeast Asia, especially to Vietnam and Cambodia [Churchman 2016: 14].

All in all, during 1991 - 2017 the amount of TIC increased because of:

1) friendly investment environment that was created by Mainland China's government at the beginning of 1990s;

2) the entry of the PRC into the WTO that improved the institutional environment for investment, strengthened Taiwanese investors' confidence to invest in Mainland China and as a result increased the amount of TIC;

3) profit-driven considerations of investors such as low labor costs in Mainland China that attracted Taiwanese entrepreneurs to move their factories to Mainland China.

The decline in the amount of TIC was caused by:

1) the Asian financial crisis in 1997 and the global financial crisis in 2008 that damaged the macroeconomic environment;

2) increasing labor costs and rising competition;

3) growing concerns of Taiwanese investors over possible Beijing's response on the DPP's policy in forms of economic sanctions.
In terms of Mainland China's investment in Taiwan, the six-decade ban from Chiang Kaishek era was lifted during Ma administration in 2009. In 2017, 1404 projects have been recorded and the total amount of investments has been 2.4 billion USD (see Fig. 3). In fact, the number of projects is smaller compared to TIC (3464 projects in 2017) as to some companies, especially state-owned enterprises, the scale of the Taiwanese market is too small to benefit from the business operations ${ }^{2}$. Thus, unlike Taiwanese counterparts, large-scale Chinese entrepreneurs invest with political goals in mind such as promoting Cross-Strait economic cooperation.

\section{Cross-Strait Tourism}

Tourism between the two sides has also been rapidly increasing (Fig. 4). Mainland China opened its doors to Taiwanese travelers first in 1987 while the Taiwanese government allowed Mainland tourists to visit Taiwan only since 2002. Major policies aimed at increasing the number of tourists from both side were implemented during Ma Ying-jeou's period and included the establishment of direct air flight in 2008 between Taiwan and Mainland China, the foundation of first tourism offices in Taipei and Beijing in 2010 and the permission of students' exchanges [Muyard 2010: 17].

The number of Taiwanese tourists in Mainland China has been increasing since 1991 with slight declines in 2002 after Chen Shuibian's speech before the 29th Annual Meeting of the World Federation of Taiwanese Associations in 2002, where he stated that Taiwan and China stood on opposite sides of the Strait, and there was one country on each side (一边一国) ${ }^{3}$. In 2010, Taiwanese tourists flow to Mainland exceeded five million. Mainland China became the main destination of Taiwanese tourists. In 2017, they amounted to almost six million.

\footnotetext{
${ }^{2}$ Cross-Strait Economic Statistics // Mainland Affairs Council. 2020. URL: http://www.mac.gov.tw (accessed: 15.05.2019).

${ }^{3}$ Yibian yi guo lun [Одна страна] // Baidu. 2002. (На китайском языке). URL: https://baike.baidu.com/item/ 一边一国论/3162848?fr=aladdin (accessed: 02.02.2019).
} 


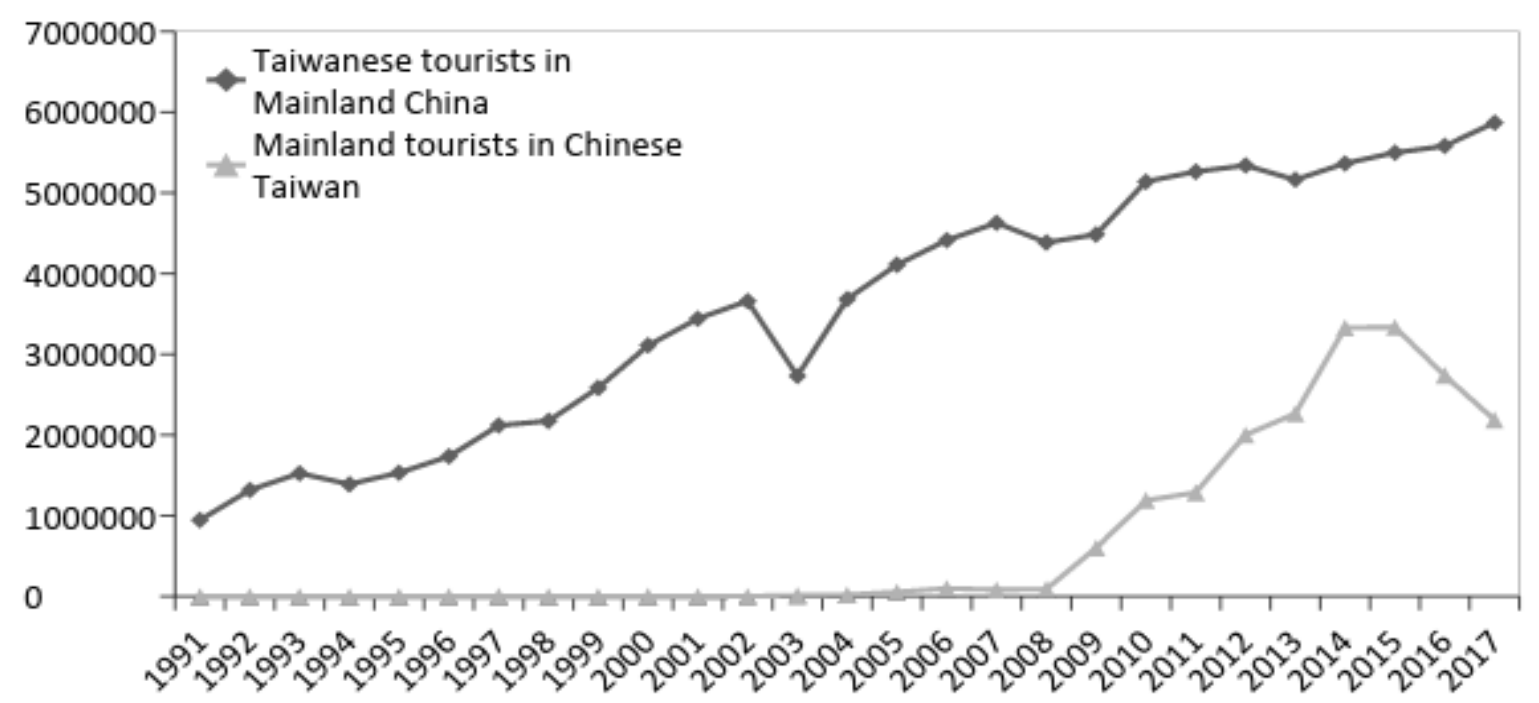

Fig. 4. Number of Travelers between Mainland China and Taiwan, 1991-2017

Source: Cross-Strait Cultural and Educational Exchanges // Mainland Affairs Council. 2020. URL: http://www.mac.gov.tw (accessed: 18.03.2019).

The number of Mainland tourists has sharply increased since 2002. In 2014, they exceeded three million people. Considering that only 90035 Mainland tourists visited Taiwan in 2008 before the ban on leisure travel was lifted the number of visitors had increased in 37 times in 6 years (see Fig. 4). However, since 2016 the number of Mainland tourists has been sharply decreasing [Fukuda 2018: 16]. The main reason is the PRC's restrictions on visiting Taiwan that are used as an instrument to force president Tsai to accept the "One China" principle and the "1992 Consensus".

Thus, tourism, unlike trade or investment, is very sensitive to political landscape that exacerbates Anti-Chinese sentiments in Taiwan. Moreover, having at their disposal many other options, people can easily change the travel destination. However, Taiwan's tourism is still very dependent on Mainland tourists and will suffer, if the decline in the number of Mainland tourists continues. The continued decrease is expected to damage not only Taiwan's tourism, but also some related areas, such as hotel industry and restaurant business.

\section{Conclusion}

The analysis of the interrelation of political and economic factors in Cross-Strait relations brings us to the following concluding remarks.
1. Political cycle in Taiwan has no impact on Cross-Strait trade that was growing at the highest speed during Chen Shui-bian's period, who had clear-cut pro-independence stance and whose actions provoked Cross-Strait tensions. Even under Ma Ying-jeou's leadership whose policy was mainly focused on improving CrossStrait relations and deepening economic ties with Mainland China, Cross-Strait trade increased at a lower speed than during Chen's period.

2. The policies of the PRC and Taiwan's administrations have created the foundation for Taiwan's investment since 1987 and since 2009 for the Mainland Chinese investment in the island's economy. The trend of Taiwan's investment outflow to Mainland China (TIC) has not been closely linked to the Taiwanese administrations' positions on Cross-Strait relations and has been more related to Taiwanese business considerations and economic motivations. The fluctuation of TIC can be caused to a large degree by the shifting economic environment and business climate in Mainland China rather than by the changing political landscape in Taiwan.

3. Mainland China's investment in Taiwan has been increasing since 2009. Unlike Taiwanese counterparts, large-scale Chinese entrepreneurs are investing with political goals in mind such as promoting Cross-Strait economic cooperation. 
4. Tourism tends to be very sensitive to political landscape as people can easily change the travel destination. Thus, Mainland China government can easily restrict the number of tourists visiting Taiwan, thereby damaging not only Taiwan's tourism sector that is highly dependent on Mainland China, but also some related areas. It has been the case since the beginning of president Tsai's tenure in 2016.
Thus, the political cycle in Taiwan has almost no or little influence on Cross-Strait trade and investment, whereas the attitude of the ruling party in Taiwan towards Mainland China and the overall political landscape have a heavy impact on people-to-people exchanges, particularly on tourism.

Received / Поступила в редакцию: 12.03.2020

Accepted / Принята к публикации: 21.06.2020

\section{References / Библиографический список}

Cabestan, J.-P., \& deLisle, J. (Eds.). (2014). Political Changes in Taiwan under Ma Ying-jeou: Partisan Conflict, Policy Choices, External Constraints and Security Challenges. New York: Routledge.

Chien-min, C. (2003). One Step Forward, One Step Backward: Chen Shui-bian's Mainland Policy. Journal of Contemporary China, 12(34), 125-143. DOI: 10.1080/10670560305460

Churchman, K. (2016). Cross-Strait Relations in the Era of Tsai Ing-wen: Shelving Differences and Seeking Common Ground? Center for the National Interest. October. URL: https://cftni.org/wp-content/uploads/2016/ 10/Churchman_Official-1.pdf (accessed: 13.02.2020).

Dagdag, E. (2005). Chen Shui-Bian and Taiwan-China (Cross-Strait) Relations: An Initial Assessment. Asian Studies, 2005, (39), 64-85. URL: https://www.asj.upd.edu.ph/mediabox/archive/ASJ-39-1-2-2003/dagdag.pdf (accessed: 12.05.2019).

Edmonds, R.L., \& Goldstein, S.M. (2001). Taiwan in the 20th Century: An Introduction. The China Quarterly, (165), 210-223. DOI: $10.1017 /$ S0009443901000006

Fell, D. (2012). Government and Politics in Taiwan. New York: Routledge.

Fukuda, M. (2018). The Current Situation and Prospects for Taiwan under the Tsai Ing-wen Administration. Washington, D.C.: HOSEI University.

Fuller, D.B. (2014). ECFA's Empty Promise and Hollow Threat. In J.-P. Cabestan \& J. deLisle (Eds.), Political Changes in Taiwan under Ma Ying-jeou: Partisan Conflict, Policy Choices, External Constraints and Security Challenges. New York: Routledge (pp. 85-99).

Jacobs, J.B., \& I-hao, B.L. (2007). Lee Teng-hui and the Idea of "Taiwan". The China Quarterly, (190), 375-393. DOI: $10.1017 / \mathrm{S} 0305741007001245$

Lin, G. (2019). Taiwan's Party Politics and Cross-Strait Relations in Evolution (2008-2018). Singapore: Palgrave Macmillan.

Lin, W. (2012). Taiwan in Ma's Second Term: International Implications. Agora Asia-Europe, 2012, (9), 1 -6.

Lychagin, A.I., \& Komarov, I.D. (2017). The Taiwan Question: External and Internal Determinants. Vestnik RUDN. International Relations, 17(3), 530 - 538. (In Russian). DOI: 10.22363/2313-0660-2017-17-3-530-538

[Лычагин А.И., Комаров И.Д. Тайваньский вопрос: внешние и внутренние детерминанты // Вестник Российского университета дружбы народов. Серия: Международные отношения. Т. 17. № 3. С. 530538. DOI: $10.22363 / 2313-0660-2017-17-3-530-538$.

Matsuda, Y. (2015). Cross-Strait Relations under the Ma Ying-jeou Administration: From Economic to Political Dependence? Journal of Contemporary East Asia Studies, 4(2), 3-35. DOI: 10.1080/24761028.2015. 11869083

Min-hua, C. (2015). China-Taiwan Rapprochement: The Political Economy of Cross-Straits Relations. Routledge.

Muyard, F. (2010). Mid-Term Analysis of the Ma Ying-jeou Administration. China Perspectives, (3), 5-20. DOI: $10.4000 /$ chinaperspectives.5299

Shaocheng, T. (2009). Relations across the Taiwan Strait: A New Era. Institute of International Relations, (21), 248-262. URL: https://www.ucm.es/data/cont/media/www/pag-72507/UNISCI\%20DP\%2021\%20-\%20 TANG.pdf (accessed: 12.08.2019).

Tsai, C. (2017). The Nature and Trend of Taiwanese Investment in China (1991-2014). In L. Dittmer (Eds.), Taiwan and China: Fitful Embrace. University of California Press (pp. 133-150). 
Tsai, T., \& Tony, T.L. (2017). Cross-Strait Relations and Regional Integration: A Review of Ma Ying-jeou Era (2008-2016). Journal of Current Chinese Affairs, 46(1), 11-35.

Wei-Cheng Wang, V. (2002). The Chen Shui-Bian Administrations Mainland Policy: Toward a Modus Vivendi or Continued Stalemate? American Asian Review, 20(3), 91-124. URL: https://digitalcommons.ithaca.edu/cgi/ viewcontent.cgi? article $=1016 \&$ context=politics_faculty_pubs (accessed: 10.09.2019).

Yitan, L., \& Enyu, Zh. (2016). Cross-Strait Relations after the 2016 Taiwan Presidential Election: The Impact of Changing Taiwanese Identity. Seattle University. P. 1-24. URL: http://www.wpsanet.org/papers/docs/ WPSA2016\%20Li\%20and\%20Zhang.pdf (accessed: 08.08.2019).

Yi-Wen, Y., Ko-Chia, Y., \& Tse-Chun, L. (2016). Political Economy of Cross-Strait Relations: Is Beijing's Patronage Policy on Taiwanese Business Sustainable? Journal of Contemporary China, 25(99), 1-17. DOI: $10.1080 / 10670564.2015 .1104871$

\begin{abstract}
About the author: Nakhatakyan Ekaterina Oganesovna - Master in Economics, Postgraduate (applicant), Department of Oriental Studies, MGIMO University (e-mail: kate-nakhatakyan@mail.ru; nakhatakyan.e.o@my.mgimo.ru).
\end{abstract}

Сведения об авторе: Нахатакян Екатерина Оганесовна - магистр экономики, соискатель кафедры востоковедения МГИМО МИД России (e-mail: kate-nakhatakyan@mail.ru; nakhatakyan.e.o@my.mgimo.ru). 